\title{
Neo-colonialism and Africa's Development: A Critical Review
}

\author{
Cyprian Uchenna Udegbunam \\ Assistant lecturer, Department of Political Science \\ Chukwuemeka Odumegwu Ojukwu University, Igbariam campus
}

\begin{abstract}
This research work accessed Nkrumah's thought on neo-colonialism and Africa's development. The broad objective of the study is to develop a framework for the complete liberation of Africa from the negative impacts of neo-colonial powers in the socio-economic and political spheres of the region. This study is set to provide answers to such questions like: How has neo-colonialism impacted on Africa's development? How can African continent be liberated from neo-colonial influences in order to achieve its economic and political independence? The study adopted the secondary source of data collection in answering the above questions. The dependency theory was adopted as its framework of analysis. The study found amongst others that: African continent are still under the shackles of neo-colonialism because in most cases, the major political economy and socio-cultural ideas, belief, norms, values, practices, structures and institutions introduced by the respective colonial imperialist powers were not dismantled after their independence. The study concluded that, for Africa to overcome the problems of neo-colonialism and its instruments, in order to gain complete economic and political independence, they should fight and struggle against the external forces which have a vested interest in keeping them underdeveloped. This study therefore, recommended amongst others that, all the ideas, belief, norms, values, practices, structures and institutions introduced by the respective colonial imperialist powers in Africa before independence, should be dismantled since the colonial days is over in Africa.
\end{abstract}

Keywords: Neocolonialism, colonialism, liberation, freedom, underdevelopment

DOI: $10.7176 / \mathrm{PPAR} / 10-10-08$

Publication date:October $31^{\text {st }} 2020$

\subsection{Background of the Study}

African states are today independent of colonialism, they remain heavily dependent and exploited under the effects of internal political failures, neo-colonialism and neo-liberalism. This dependency and exploitation particularly through the activities of Trans National Corporations, adversely affects the living conditions of millions of people in Africa, creating economic hardship and in some cases encouraging political repression. These problems can be linked to the crisis of underdevelopment in Africa and the attendant dependency problem.

Nkrumah Kwame, (1965: ix), stated that the essence of neo-colonialism is that the state which is subject to it is, in theory, independent and has all the outward trappings of international sovereignty. In reality, its economic system and thus its political policy is directed from outside. He further maintained that neocolonialism is also the worst form of imperialism. "For those who practice it, it means power without responsibility, and for those who suffer from it, it means, exploitation without redress". This is because, in the days of old fashioned colonialism, the imperial powers had at least to explain and justify at home actions it was taking abroad Mbah, (2006, p. 66). With neo-colonialism, this is not the case. Nkrumah may not be far from the truth because in the halcyon days of colonialism, the imperial powers were accountable to their respective home government Odoziobodo \& Ommemma, (1999, p. 97). More importantly, their opponents protected the colonies being protectorates of their colonizers against all forms of violence. But in neo-colonial states, the reverse is the case. Neo-colonial states are made the punching bag or the playing field of the international big players for the sale and taste of their manufactured weapon. According to Chikendu (2004, p. 123), this sum up its meaning and its essence, we have seen that after the Second World War, colonialism and imperialism became obnoxious to sensibilities of all civilized men and women except their practitioners.

Neocolonialism is those modern attempts to perpetuate colonialism while at the same time talking about freedom or independence. One of the major problems that have constituted a stumbling block to the development of the post-independent African countries is neo-colonialism Odoziobodo \& Ommemma, (1999, p. 97). Neocolonialism is the highest stage of imperialism. It is the tactics which imperialism switched over to when it was confronted with the militant peoples of the ex-colonial territories in Asia, Africa, the Caribbean and Latin America Nkrumah, (1963: ix-xx). Essentially, neo-colonial societies are in principle independent and have all the outward trappings of international sovereignty.

More so, neo-colonialism provides enormous profits as did colonialism before it. Nkrumah describes how Western monopolies control the prices of commodities by lowering the prices they pay and extracting some $\$ 41$ billion in profits from 1951 to $1961 \ldots$ Also they profit from high rates of interest: "while capital worth $\$ 30,000$ million was exported to some fifty-six developing countries between 1956 and 1962, it is estimated that interest and profit alone extracted on this sum from the debtor countries amounted to more than $£ 15,000$ million." 
According to Odoziobodo \& Ommemma, (1999, p. 99), their economic systems and thus their political policy is in reality shaped and imposed from outside. It is akin to a divorce with alimony since all neocolonial states are not masters of their own fate. Also, according to a dictionary of political economy, "neo-colonialism is a system of economic, political, military and other relations imposed by the imperialist states on the developing countries in order to keep them within the framework of the capitalist economic system (Volkov, (eds.) (1981, p. 247). It is based on the economic backwardness, unequal and dependent state of the neocolonial countries within the scheme of the world capitalist economic and political systems.

At the time he published Neo-Colonialism, the last Stage of Imperialism, Kwame Nkrumah was the President of Ghana, the first African country to achieve independence from colonial rule. One year later he would be deposed by a military coup that was supported by the American CIA. The name of Nkrumah's book is a variation on Lenin's own study of imperialism written 50 years before and named Imperialism: The Highest Stage of Capitalism. This is fitting because Nkrumah's contribution remains the best single update on imperialism since Lenin.

Nkrumah explains in great detail how the West, and especially the United States, was responding to the success of national liberation movements, such as the one he led in Ghana, by shifting its tactics from colonialism to neo-colonialism: "Without a qualm it dispenses with its flags" and "claims that it is 'giving' independence to its former subjects, to be followed by 'aid' for their development. Under cover of such phrases, however, it devises innumerable ways to accomplish objectives formerly achieved by naked colonialism."

The neo-colonial powers pursue their actions in the name of the United Nations by using two UN agencies that they established after World War and that they fully control without any pretext of democracy, the World Bank and the International Monetary Fund: "Still another neo-colonialist trap on the economic front has come to be known as 'multilateral aid' through international organizations: the International Monetary Fund, the Inter-national Bank for Reconstruction and Development (known as the World Bank), the International Finance Corporation and the International Development Association are examples, all, significantly, having U.S. capital as their major backing. These agencies have the habit of forcing would-be borrowers to submit to various offensive conditions, such as supplying information about their economies, submitting their policy and plans to review by the World Bank and accepting agency supervision of their use of loans.

Again, among the "innumerable ways" of neo-colonialist exploitation, Nkrumah describes the following. "There are conditions which hedge it around: the conclusion of commerce and navigation treaties; agreements for economic co-operation; the right to meddle in internal finances, including currency and foreign exchange, to lower trade barriers in favour of the donor country's goods and capital; to protect the interests of private investments; determination of how the funds are to be used; forcing the recipient to set up counterpart funds; to supply raw materials to the donor; and use of such funds a majority of it, in fact to buy goods from the donor nation. These conditions apply to industry, commerce, agriculture, shipping and insurance, apart from others which are political and military. So-called 'invisible trade' furnishes the Western monopolies with yet another means of economic penetration. Over 90 per cent of world ocean shipping is controlled by the imperialist countries ... As for insurance payments; in 1961 alone these amounted to an unfavourable balance in Asia, Africa and Latin America of some additional $\$ 370$ million.

As shown by the Nkrumah analysis, Neo-colonial exploitation "operates not only in the economic field, but also in the political, religious, ideological and cultural spheres." Neo-colonialism or new form of colonialism is achieved through the economic system of the new state. According to Chikend (2004), before leaving, the imperialists had structured the economic system of the colony in such a way that it must depend wholly on the imperial nations for its growth. The old imperial power controls the monetary system. Thus the neo-colonial state often finds itself obliged to take the manufactured goods of the imperialist power to the exclusion of competing products from elsewhere: its trades are monopolized by the imperialist power. Other methods of control to maintain old dependency relations include control over government policy in the neo-colonial state by payments towards the cost of running the state, by provision of civil servants in positions where they can dictate policy, and by monetary control over foreign exchange through the imposition of a banking system controlled by the imperial power.

However, neo-colonialism is the dominance of strong nations over weak nations, not by direct political control as in traditional colonialism. The imperial powers have numerous agents that help them to actualize their neocolonial intentions. These include the International Monetary Fund IMF, the World Bank, Multi-national Corporations MNCs, etc. world over, nationalists of the colonized countries struggled hard and gained independence for their countries. But this independence was essentially nominal and empty (Chikendu, 2004). These countries were not really independent. The departing colonial masters did not want them to be fully independent; they had contrived through various ways to make them dependent on them (the colonialists). It is this fact that we call neo-colonialism and neo-imperialism

\subsection{Statement of the research problem}

Colonialism is a phenomenon through which the powerful European countries exploited the wealth and natural 
resources of the weak countries whom they subjected to their rule and authority. Neo-colonialism is evident in the unmitigated domination of all the sectors of the economy by the imperialists. The nationalists of these weak countries succeeded to win political or flag independence, but discovered to their dismay that a new form of colonialism- neo-colonialism has been foisted on them, which is essentially economic, political, religious, ideological and cultural in nature. Neo-colonialism is a term used to describe certain economic operations at the international level which have alleged similarities to the traditional colonialism of the 16th to 19th centuries. The general contention is that governments have aimed to control other nations through indirect means; that in lieu of direct military-political control, neo-colonialist powers employ economic, financial and trade policies to dominate less powerful countries.

Neo-colonialism is a policy whereby a major power uses economic and political means to perpetuate or extend its influence over underdeveloped nations. It is the dominance of strong nations over weak nations, not by direct political control as in traditional colonialism. The major problem being that neo-colonialism operates through the various imperialist links earlier put in place by the colonial powers before and during the era of colonialism. It is possible because, in most cases, the major political economic and socio-cultural ideas, belief, norms, values, practices, structures and institutions introduced by the respective colonial imperialist powers were not dismantled at independence.

To say that Africa is in an economic crisis is a great understatement. Basic infrastructure in most African countries is dilapidated, economic growth is minimal, access to the basics like food, health and education is sparse and expensive, arid areas are encroaching into previously arable land, and so on and so forth. The list is enormous. All this while, the continent is deeply entrenched in debt to the developed Western countries, much of these debts was acquired to fight the economic hardships, but has obviously failed to make any remarkable improvement in the situation.

At independent, people celebrated that at least they could enjoy their own freedom and government dominated by people who will serve their interest. But as time went on, it dawned on them that they are still under some of control by the colonial masters, this time a new form or advance method of domination called Neo-colonialism. The colonial masters after departing from Africa still left behind; structures, institutions and authorities. Also they built a ruling class called the comprador bourgeoisie, so this time they dominated Africa through the comprador bourgeoisie set up by them to continue their activities of exploitation. Neo colonialism means new colonialism, that is, it is the new form of colonialism, it is the domination of a country through indirect means such as loans from International Monetary Fund (I.M.F) and World Bank to third world countries, multi-national co-operations etc. it is the exploitation without redress (Nkrumah, 1974). Up till today, it has not been possible to win the struggle against this new form of colonialism, but the struggle continues. This study is therefore an attempt to fill this gap in knowledge. It is in the light of this, that we explore the following research questions to guide this study:

\subsection{Significance of the Study}

First, the significance of this present study derives from the fact that it represents an attempt to fill a research gap. The study shall provide policy options that could benefit African legislators (law makers) including Nigeria who may be in dare need of good policies to fix the negative impacts of neo-colonialism in the country. Second, the students of political science and international relations may find it necessary to use this work in improving their knowledge of the legacies of neo-colonialism in Africa. Also, researchers could as well benefit from it by making it a reference material while carrying out research on similar topics.

\subsection{Scope and Limitations of the Study}

Although much has been written about neo-colonialism in Africa the search that preceded the commencement of this study revealed no previous investigation aimed at: Establishing any relationship between neo-colonialism in Africa and the possibility of true independence for the continent. This study shall therefore, focus on the Nkrumah's thought on Neo-colonialism in Africa considering their current situation. The study will focus on filling the lacuna (the gap) in the literatures by determining the current status of Africa in terms of neo-colonialism, and establishing if there is any relationship between neo-colonialism in Africa and to find the possibility of true independence for the continent. The limited research materials as at the time of the study affected the presumed timing for the research while financial constraints contributed to the limitations of the study.

\subsubsection{Conceptual Review}

Several studies on the theme of neocolonialism have been conducted and are still going on to examine the impact of neocolonialism on developing countries in Africa as the case may be. To understand how neocolonialism has impacted the developing countries of Africa, it would be imperative to also understand the present status quo in African societies. With that in mind, it is no news that Africa is poverty stricken and misery ridden society. It is also no secret that Africa is wallowing extremely, well behind other developing nations in Asia and South America, and definitely centuries behind the Western civilizations 'the United States and Western Europe'. It is the result of the above that led Nyikal (2005) to submit that Africa is deep in debt, hunger, diseases, illiteracy and civil strife. 
Many argue that the condition in Africa is in fact far worse today than it was at the end of colonialism under the European nations in the 1960s and 1970s. Observing the living conditions of the rapidly growing population, it is apparent that this is actually the case.

One of the foremost proponents of neo colonialism was the former Ghanaian leader Kwame Nkrumah who described neo-colonialism as the worst form of imperialism and capitalist exploitation. The essence of neocolonialism is that the State that is subject to it is, in theory, independent and has all the outward trappings of international sovereignty. In reality, its economic system and thus its political policy is directed from outside. Foreign capital is used for exploitation rather than development of less developed countries; investment increases gap between rich and poor and all aids given to neo-colonial state returns to the imperialist country.

\subsubsection{Workings of Neo Colonialism}

Largely because of the world capitalist system and the so-called international division of labour which sees Africa only as producers of primary commodities, most African nations have no viable integrated industries which can diversify their economies and supply the rest of the world with finished products. Mining production for example is destined principally for exportation. What stays in Africa is the wages paid for the mineworkers. A majority of money spent on salaries goes to Western directors, and much of the profit goes to Western Trans-national corporations.

Two examples: 1) Debeers and the diamond trade in Angola, Sierra Lone and the Congo that has encouraged the war in these countries and impoverished them. A recent UN report implicated Western firm and countries including Belgium in the illegal diamond trade. 2) Shell in Nigeria and the Ogoni crisis which led to the state execution of the environmental right activist Ken Saro Wiwa

African states often do not have very much capital with which to initiate or sustain industrialization. Although agriculture is important, industrialization is equally important in today's industrial world. African states often do not get fair prices for their primary export commodities, which are usually their only source of income. This is because they have little control over the international money market. The prices of primary commodities such as cocoa, timber, rubber have all collapsed. For many years, inflation in the prices of imported consumer good has affected Africans without anyone coming to their aid

\subsubsection{Obstacles to Neocolonialism}

The global outcry and opposition over the inequitable trade regulations being put in place by the World Trade Organization has drawn attention to the inequities in the global economic system. The demonstrations in Seattle against the WTO meeting there are an example of this growing awareness. At no other time in history has there been greater disparity between very rich nations and very poor nations.

Nations in the West are forming coalitions to integrate protect their economies (NAFTA in North America and the European Union in Europe). Yet at the same time, poor developing countries in Africa, Asia and Latin America are continually urged by the World Bank and the IMF to liberalize and remove protectionist policies from their economic programs. For Africa, redressing this is an urgent challenge. Neo-colonialism and neo liberalism make continental planning harder over time, because narrow national markets becomes structurally entrenched.

However, Neo-colonialism alone does not fully explain Africa's present-day developmental challenges. There is also the question of corruption and the failures of political leadership. Some scholars would even suggest that the whole notion of "neo-colonialism" as proffered by post-colonial leaders like Nkrumah enable them to deflect criticisms of their own failures and instead place the blame on external factors.

However, two major material base of neo-colonialism are the integration of the neo-colonial states into the system of the international capitalist division of labour and the consequent peripherization of their economies to the centre of the international capitalist system (Odoziobodo \& Omemma, 1999, p. 98). The second is the retention of important positions in the vital economic sectors of the neo-colonial states by the foreign financial capital. Also, neo-colonialism is the survival of the colonial system in spite of formal recognition of political independence in emerging countries, which became the victims of an indirect and subtle form of domination by political, economic, social, military or technical forces (Brown, 1978, p. 225). Thus neo-colonialism in practical terms involves continuing economic dependence on the former colonial overlords, superficial integration of the neo-colonial countries into neo-colonial economic and socio-political blocs and infiltration through foreign capital investments, aid and technical partnerships.

Even though neo-colonialism is a direct offshoot of colonialism in its classical sense, it not only exists in countries that were not colonized in Africa Liberia, Egypt and Ethiopia, but championed by a power that never colonized any country, the United States of America. As a modern equivalent of decayed colonialism, the imperialist stage of capitalist expansion and development on a global scale marked the historical origin of neocolonialism. As we pointed out earlier, the culmination into direct seizure of African lands through conquest and military operations was necessitated by the search for external sources of capital and profits by individual merchants and later transnational corporations from Western Europe. Such imperialist operations and adventures resulted in formal colonization of territories and peoples worldwide. 


\subsubsection{Empirical Review}

During the last half of the twentieth century, Africans went through profound changes that enabled them loosen the yoke of classical colonialism (Egbomuche, 2006, p. 64). While there were a myriad of key personalities and organizations that put the mass of African subjects and well wishers on the path to political independence, some names shine brighter than others. Kwame Osagyefo Nkrumah is among those names that shine brightest.

Mbah (2006, p. 64), maintained that a classical contribution of Kwame Nkrumah to African political thought and practice is his work Neo-Colonialism: The Last Stage of Imperialism. This is the book which, when first published in 1965, caused such uproar in the US State Department that a sharp note of protest was sent to Kwame Nkrumah, and the \$25 million of American "aid" to Ghana was promptly cancelled. It exposes the working of international monopoly capitalism in Africa and shows how the strangleholds of foreign monopolies perpetuate the paradox of Africa: poverty in the midst of plenty. Nkrumah began his work with re-definition of neocolonialism. Accordingly, he sees neo-colonialism of today as representing imperialism in its final and perhaps, its most dangerous stage. Nkrumah laments that imperialism still constitutes an African problem, but it is everywhere on retreat. In place of colonialism as the main instrument of imperialism we have today neo-colonialism.

The result of neo-colonialism is that foreign capital is used for the exploitation rather than for the development of the less developed parts of the world. Investment under the neo-colonial increases rather than decreases the gap between the rich and poor countries of the world. Nkrumah argues further that a state in the grip of neo-colonialism is not master of its own destiny. It is this factor which makes neo-colonialism such a serious threat to world peace. Neo-colonialism, he asserts, is an attempt to export the social conflicts of capitalism of the capitalist countries. But the internal contradictions and conflicts of neo-colonialism make it certain that it cannot endure as a permanent world policy. Nkrumah states unequivocally that neo-colonialism is by no means exclusively an African question. Long before it was practiced on any large scale in Africa; it was an established system in other parts of the world. The less developed will not become developed through the goodwill or generosity of the developed powers. It can only become developed through a struggle against the external forces which has a vested interest in keeping it underdeveloped. Of these forces, neo-colonialism is at this stage of history, the principal. On neo-colonialism in Africa, Nkrumah says that the greatest danger at present facing Africa is neo-colonialism and its major instrument, balkanization.

In his book, Neo-Colonialism: the Last stage of imperialism (1965: ix), Nkrumah Kwame, stated that the essence of neo-colonialism is that the state which is subject to it is, in theory, independent and has all the outward trappings of international sovereignty. In reality, its economic system and thus its political policy is directed from outside. He further maintained that neocolonialism is also the worst form of imperialism. "For those who practice it, it means power without responsibility, and for those who suffer from it, it means exploitation without redress". In the late 19th century, the European imperial powers staged a major "scramble for Africa" and occupied most of the continent, creating many colonial nation states and leaving only two independent nations: Liberia, the black African colony, and Orthodox Christian Abyssinia (Ethiopia.) Egbomuche, (2006:134). This colonial occupation continued until after the conclusion of World War II when all the colonial states gradually obtained formal independence. Today, Africa is home to over 50 independent countries, which mostly have the borders drawn during the era of European colonialism (Maswood, 2012). The Africanist philosophy of colonialism and neocolonialism is rooted on the lack of consensus among African theorists on the legacy of colonialism. There is however, a titling of the weighing balance in favour of the African thinkers who hold the view that most African countries still only totter on their feet and many close to collapse due to Africa's colonial experience.

The neo-colonialism of today represents imperialism in its final and perhaps, its most dangerous stage. In the past it was possible to convert a country upon which a neo-colonial regime had been imposed. Egypt is an example into a colonial territory in the nineteenth century. Today this process is no longer feasible. Old-fashioned colonialism is by no means entirely abolished. It still constitutes an African problem, but it is everywhere on the retreat. Once a territory has become nominally independent it is no longer possible, as it was in the last century, to reverse the process. Existing colonies may linger on, but no new colonies will be created. In place of colonialism as the main instrument of imperialism, what survives today is neo-colonialism. The essence of neo-colonialism is that the State which is subject to it is, in theory, independent and has all the outward paraphernalia of international sovereignty. In reality its economic system and thus its political policy is directed from outside (Amponash, 2010).

The methods and form of this direction can take various shapes. For example, in an extreme case, the troops of the imperial power may garrison the territory of the neo-colonial State and control its government. More often, however, neo-colonialist control is exercised through economic or monetary means. The neo-colonial State may be obliged to take the manufactured products of the imperialist power to the exclusion of competing products from elsewhere. Control over government policy in the neo-colonial State may be secured by payments towards the cost of running the State, by the provision of civil servants in positions where they can dictate policy, and by monetary control over foreign exchange through the imposition of a banking system controlled by the imperial power (Rahaman, Yeazdani \& Mahmud, 2017).

Where neo-colonialism exists the power exercising control is often the State which formerly ruled the territory 
in question, but this is not necessarily so. For example, in the case of South Vietnam the former imperial power was France, but neo-colonial control of the State has now gone to the United States. It is possible that neo-colonial control may be exercised by a consortium of financial interests which are not specifically identifiable with any particular State (Mark, 2017). The control of the Congo by great international financial concerns is a case in point. The result of neo-colonialism is that foreign capital is used for the exploitation rather than for the development of the less developed parts of the world. Investment under neo-colonialism increases rather than decreases the gap between the rich and the poor countries of the world (Pather, 2019). The struggle against neo-colonialism is not aimed at excluding the capital of the developed world operating in less developed countries. It is aimed at preventing the financial power of the developed countries being used in such a way as to impoverish the less developed.

Non-alignment, as practiced by Ghana and many other countries, is based on co-operation with all States whether they are capitalist, socialist or have a mixed economy. Such a policy, therefore, involves foreign investment from capitalist countries, but it must be invested in accordance with a national plan drawn up by the government of the non-aligned State with its own interests in mind. The issue is not what returns the foreign investor receives on his investments. He may, in fact, do better for himself if he invests in a non-aligned country than if he invests in a neo-colonial one. The question is one of power. A State in the grip of neo-colonialism is not master of its own destiny (Nkrumah 1965 in Babatola, 2014). It is this factor which makes neo-colonialism such a serious threat to world peace. The growth of nuclear weapons has made out of date the old-fashioned balance of power which rested upon the ultimate sanction of a major war. Certainty of mutual mass destruction effectively prevents either of the great power blocs from threatening the other with the possibility of a world-wide war, and military conflict has thus become confined to 'limited wars'. For these neo-colonialism is the breeding ground.

Such wars can, of course, take place in countries which are not neo-colonialist controlled. Indeed their object may be to establish in a small but independent country a neo-colonialist regime. The evil of neo-colonialism is that it prevents the formation of those large units which would make impossible 'limited war'. To give one example: if Africa was united, no major power bloc would attempt to subdue it by limited war because from the very nature of limited war, what can be achieved by it is itself limited. It is, only where small States exist that it is possible, by landing a few thousand marines or by financing a mercenary force, to secure a decisive result (Anuoluwapo \& Edwin, 2018).

The restriction of military action of 'limited wars' is, however, no guarantee of world peace and is likely to be the factor which will ultimately involve the great power blocs in a world war, however much both are determined to avoid it.

Limited war, once embarked upon, achieves a momentum of its own. Of this, the war in South Vietnam is only one example. It escalates despite the desire of the great power blocs to keep it limited. While this particular war may be prevented from leading to a world conflict, the multiplication of similar limited wars can only have one end-world war and the terrible consequences of nuclear conflict.

Neo-colonialism is also the worst form of imperialism. For those who practice it, it means power without responsibility and for those who suffer from it, it means exploitation without redress. In the days of old-fashioned colonialism, the imperial power had at least to explain and justify at home the actions it was taking abroad (Anuoluwapo and Edwin, 2018). In the colony those who served the ruling imperial power could at least look to its protection against any violent move by their opponents. With neo-colonialism neither is the case.

Above all, neo-colonialism, like colonialism before it, postpones the facing of the social issues which will have to be faced by the fully developed sector of the world before the danger of world war can be eliminated or the problem of world poverty resolved.

Neo-colonialism, like colonialism, is an attempt to export the social conflicts of the capitalist countries. The temporary success of this policy can be seen in the ever widening gap between the richer and the poorer nations of the world. But the internal contradictions and conflicts of neo-colonialism make it certain that it cannot endure as a permanent world policy. How it should be brought to an end is a problem that should be studied, above all, by the developed nations of the world, because it is they who will feel the full impact of the ultimate failure. The longer it continues the more certain it is that its inevitable collapse will destroy the social system of which they have made it a foundation.

The reason for its development in the post-war period can be briefly summarized. The problem which faced the wealthy nations of the world at the end of the Second World War was the impossibility of returning to the prewar situation in which there was a great gulf between the few rich and the many poor. Irrespective of what particular political party was in power, the internal pressures in the rich countries of the world were such that no post-war capitalist country could survive unless it became a 'Welfare State'. There might be differences in degree in the extent of the social benefits given to the industrial and agricultural workers, but what was everywhere impossible was a return to the mass unemployment and to the low level of living of the pre-war years.

From the end of the nineteenth century onwards, colonies had been regarded as a source of wealth which could be used to mitigate the class conflicts in the capitalist States and, as will be explained later, this policy had 
some success. But it failed in 'its ultimate object because the pre-war capitalist States were so organized internally that the bulk of the profit made from colonial possessions found its way into the pockets of the capitalist class and not into those of the workers. Far from achieving the object intended, the working-class parties at times tended to identify their interests with those of the colonial peoples and the imperialist powers found themselves engaged upon a conflict on two fronts, at home with their own workers and abroad against the growing forces of colonial liberation.

The post-war period inaugurated a very different colonial policy. A deliberate attempt was made to divert colonial earnings from the wealthy class and use them instead generally to finance the 'Welfare State'. As will be seen from the examples given later, this was the method consciously adopted even by those working-class leaders who had before the war regarded the colonial peoples as their natural allies against their capitalist enemies at home.

At first it was presumed that this object could be achieved by maintaining the pre-war colonial system. Experience soon proved that attempts to do so would be disastrous and would only provoke colonial wars, thus dissipating the anticipated gains from the continuance of the colonial regime. Britain, in particular, realized this at an early stage and the correctness of the British judgment at the time has subsequently been demonstrated by the defeat of French colonialism in the Far East and Algeria and the failure of the Dutch to retain any of their former colonial empire.

The system of neo-colonialism was therefore instituted and in the short run it has served the developed powers admirably. It is in the long run that its consequences are likely to be catastrophic for them.

Neo-colonialism is based upon the principle of breaking up former large united colonial territories into a number of small non-viable States which are incapable of independent development and must rely upon the former imperial power for defence and even internal security. Their economic and financial systems are linked, as in colonial days, with those of the former colonial ruler.

At first sight the scheme would appear to have many advantages for the developed countries of the world. All the profits of neo-colonialism can be secured if, in any given area, a reasonable proportion of the States have a neo-colonialist system. It is not necessary that they all should have one. Unless small States can combine they must be compelled to sell their primary products at prices dictated by the developed nations and buy their manufactured goods at the prices fixed by them. So long as neo-colonialism can prevent political and economic conditions for optimum development, the developing countries, whether they are under neo-colonialist control or not, will be unable to create a large enough market to support industrialization. In the same way they will lack the financial strength to force the developed countries to accept their primary products at a fair price.

In the neo-colonialist territories, since the former colonial power has in theory relinquished political control, if the social conditions occasioned by neo-colonialism cause a revolt the local neo-colonialist government can be sacrificed and another equally subservient one substituted in its place. On the other hand, in any continent where neo-colonialism exists on a wide scale the same social pressures which can produce revolts in neo-colonial territories will also affect those States which have refused to accept the system and therefore neo-colonialist nations have a ready-made weapon with which they can threaten their opponents if they appear successfully to be challenging the system.

These advantages, which seem at first sight so obvious, are, however, on examination, illusory because they fail to take into consideration the facts of the world today.

The introduction of neo-colonialism increases the rivalry between the great powers which was provoked by the old-style colonialism. However little real power the government of a neo-colonialist State may possess, it must have, from the very fact of its nominal independence, a certain area of maneuver. It may not be able to exist without a neo-colonialist master but it may still have the ability to change masters.

The ideal neo-colonialist State would be one which was wholly subservient to neo-colonialist interests but the existence of the socialist nations makes it impossible to enforce the full rigour of the neo-colonialist system. The existence of an alternative system is itself a challenge to the neo-colonialist regime. Warnings about 'the dangers of Communist subversion are likely to be two-edged since they bring to the notice of those living under a neo-colonialist system the possibility of a change of regime. In fact neo-colonialism is the victim of its own contradictions. In order to make it attractive to those upon whom it is practiced it must be shown as capable of raising their living standards, but the economic object of neo-colonialism is to keep those standards depressed in the interest of the developed countries. It is only when this contradiction is understood that the failure of innumerable 'aid' programmes, many of them well intentioned, can be explained.

In the first place, the rulers of neo-colonial States derive their authority to govern, not from the will of the people, but from the support which they obtain from their neo-colonialist masters. They have therefore little interest in developing education, strengthening the bargaining power of their workers employed by expatriate firms, or indeed of taking any step which would challenge the colonial pattern of commerce and industry, which it is the object of neo-colonialism to preserve. 'Aid', therefore, to a neo-colonial State is merely a revolving credit, paid by the neo-colonial master, passing through the neo-colonial State and returning to the neo-colonial master in the form of increased profits. 
Secondly, it is in the field of 'aid' that the rivalry of individual developed States first manifests itself. So long as neo-colonialism persists so long will spheres of interest persist, and this makes multilateral aid which is in fact the only effective form of aid impossible.

Once multilateral aid begins the neo-colonialist masters are faced by the hostility of the vested interests in their own country. Their manufacturers naturally object to any attempt to raise the price of the raw materials which they obtain from the neo-colonialist territory in question, or to the establishment there of manufacturing industries which might compete directly or indirectly with their own exports to the territory. Even education is suspect as likely to produce a student movement and it is, of course, true that in many less developed countries the students has been in the vanguard of the fight against neo-colonialism.

In the end the situation arises that the only type of aid which the neo-colonialist masters consider as safe is 'military aid'.

Once a neo-colonialist territory is brought to such a state of economic chaos and misery that revolt actually breaks out then, and only then, is there no limit to the generosity of the neo-colonial overlord, provided, of course, that the funds supplied are utilized exclusively for military purposes.

Military aid in fact marks the last stage of neo-colonialism and its effect is self-destructive. Sooner or later the weapons supplied pass into the hands of the opponents of the neo-colonialist regime and the war itself increases the social misery which originally provoked it.

Neo-colonialism is a mill-stone around the necks of the developed countries which practice it. Unless they can rid themselves of it, it will drown them. Previously the developed powers could escape from the contradictions of neo-colonialism by substituting for it directs colonialism. Such a solution is no longer possible and the reasons for it have been well explained by Mr. Owen Lattimore, the United States Far Eastern expert and adviser to Chiang Kai-shek in the immediate post-war period. He wrote:

Asia, which was so easily and swiftly subjugated by conquerors in the eighteenth and nineteenth centuries, displayed an amazing ability stubbornly to resist modern armies equipped with Aeroplanes, tanks, motor vehicles and mobile artillery.

Formerly big territories were conquered in Asia with small forces. Incomes, first of all from plunder, then from direct taxes and lastly from trade, capital investments and long-term exploitation, covered with incredible speed the expenditure for military operations. This arithmetic represented a great temptation to strong countries. Now they have run up against arithmetic, and it discourages them.

The same arithmetic is likely to apply throughout the less developed world.

This book is therefore an attempt to examine Nkrumah's thought on neo-colonialism in its African context and its relation to African unity and development. Neo-colonialism is by no means exclusively an African question. Long before it was practiced on any large scale in Africa it was an established system in other parts of the world. Nowhere has it proved successful, either in raising living standards or in ultimately benefiting countries which have indulged in it.

Marx predicted that the growing gap between the wealth of the possessing classes and the workers it employs would ultimately produce a conflict fatal to capitalism in each individual capitalist State.

This conflict between the rich and the poor has now been transferred on to the international scene, but for proof of what is acknowledged to be happening it is no longer necessary to consult the classical Marxist writers. The situation is set out with the utmost clarity in the leading organs of capitalist opinion. Take for example the following extracts from The Wall Street Journal, the newspaper which perhaps best reflects United States capitalist thinking.

In its issue of 12 May 1965, under the headline of 'Poor Nations' Plight', the paper first analyses 'which countries are considered industrial and which backward'. There is, it explains, 'no rigid method of classification'. Nevertheless, it points out:

A generally used breakdown, however, has recently been maintained by the International Monetary Fund because, in the words of an IMF official, "the economic demarcation in the world is getting increasingly apparent." The break-down, the official says, "is based on simple common sense.",

In the IMF's view, the industrial countries are the United States, the United Kingdom, most West European nations, Canada and Japan. A special category called "other developed areas" includes such other European lands as Finland, Greece and Ireland, plus Australia, New Zealand and South Africa. The IMF's "less developed" category embraces all of Latin America and nearly all of the Middle East, non-Communist Asia and Africa.'

In other words the 'backward' countries are those situated in the neo-colonial areas. After quoting figures to support its argument, The Wall Street Journal comments on this situation: The industrial nations have added nearly $\$ 2$ billion to their reserves, which now approximate $\$ 52$ billion. At the same time, the reserves of the lessdeveloped group not only have stopped rising, but have declined some \$200 million. To analysts such as Britain's Miss Ward, the significance of such statistics is clear: the economic gap is rapidly widening "between a white, complacent, highly bourgeois, very wealthy, very small North Atlantic elite and everybody else, and this is not a very comfortable heritage to leave to one's children." 
"Everybody else" includes approximately two-thirds of the population of the earth, spread through about 100 nations.' This is no new problem. In the opening paragraph of his book, The War on World Poverty, written in 1953, the present British Labour leader, Mr. Harold Wilson, summarized the major problem of the world as he then saw it: 'For the vast majority of mankind the most urgent problem is not war, or Communism, or the cost of living, or taxation. It is hunger. Over 1,500,000,000 people, some-thing like two-thirds of the world's population, are living in conditions of acute hunger, defined in terms of identifiable nutritional disease. This hunger is at the same time the effect and the cause of the poverty, squalor and misery in which they live.'

Its consequences are likewise understood. The correspondent of The Wall Street Journal previously quoted, underlines them: Many diplomats and economists view the implications as overwhelmingly and dangerously political. Unless the present decline can be reversed, these analysts fear, the United States and other wealthy industrial powers of the West face the distinct possibility, in the words of British economist Barbara Ward, "of a sort of international class war".'

What are lacking are any positive proposals for dealing with the situation. All that The Wall Street Journal's correspondent can do is to point out that the traditional methods recommended for curing the evils are only likely to make the situation worse. It has been argued that the developed nations should effectively assist the poorer parts of the world, and that the whole world should be turned into a Welfare State. However, there seems little prospect that anything of this sort could be achieved. The so-called 'aid' programmes to help backward economies represent, according to a rough U.N. estimate, only one half of one per cent of the total income of industrial countries. But when it comes to the prospect of increasing such aid the mood is one of pessimism:

'A large school of thought holds that expanded share-the-wealth schemes are idealistic and impractical. This school contends climate, undeveloped human skills, lack of natural resources and other factors not just lack of money retard economic progress in many of these lands, and that the countries lack personnel with the training or will to use vastly expanded aid effectively. Share-the-wealth schemes, according to this view, would be like pouring money down a bottomless well, weakening the donor nations without effectively curing the ills of the recipients.'

The absurdity of this argument is demonstrated by the fact that every one of the reasons quoted to prove why the less developed parts of the world cannot be developed applied equally strongly to the present developed countries in the period prior to their development. The argument is only true in this sense. The less developed world will not become developed through the goodwill or generosity of the developed powers. It can only become developed through a struggle against the external forces which have a vested interest in keeping it undeveloped.

Buttressing the above points, Sofola, (1978: 39) maintained that the Chief causes of colonialism and imperialism is "economy". The quest for physical satisfaction has been one of the aims of life. The Hedonist philosophers are like all of us humans. They have sought to minimize pain and maximize joy and comfort. Karl Marx associated this human aim or quest with the economic interpretation of history. If goods are to be produced, they must be consumed or else there would be an over-production and there would be economic crisis. Since commercial and industrial revolutions, nations have encouraged commercial relations. Raw materials were needed in order to manufacture goods. From these have come the needs for the preservation of the precious metals. Turgort and other physiocrats, including Adam Smith, proclaimed the "laissez-fair" theory of trade, whilst the mercantilists pleaded for the conservation of precious metals. These aided in giving impetus to imperialism which culminated in the acquisition of colonial empire for the monopolization of the home industries of the metropolitan powers.

On the Africanist theory of neo-colonialism, African theorists and nationalists argue that the so-called independence gained from the withdrawal of colonial powers is nothing more than a cosmetic and partial liberation and regard the whole affair as false independence. According to Egbomuche (2006), Africans believe that real, sustainable independence can only be achieved with economic independence. African nations are said to be currently in a phase of neo-colonialism, a new form of imperial rule stage-managed by the colonial powers to give the colonized the illusion of freedom. Based on this contention, at the 1961 All African People's Conference held in Cairo, neo-colonialism was defined as; "The survival of the colonial system in spite of the formal recognition of political independence in emerging countries which becomes the victims of an indirect and subtle form of domination by political, economic, social, military or technical means".

Therefore, African political theorists hold the view that western powers still control African nations whose ruler are either willing puppets or involuntarily subordinates of these powers. The economies of African nations are structured, by virtue of their colonial experiences to serve international capitalism. The natural resources of the satellites are exploited for use in the centre.

The means of production are owned by foreign corporations who employ various means to transfer profit out of the country rather than invest them in local economy. So what African countries experience is "development of underdevelopment". This position was seriously canvassed by Prof. Clude Ake in his book, The political Economy of Africa. Other Africans advocates of this thesis include Prof. Esko Toyo, Bade Onimode, Walter Rodney, Ikenna Nzimiro, Pade Badru, Julius Ihonvbere, Kimse Okoko, Chinweizu, Frantz Fanon and many others.

These theorists further contend that the unequal relations between developed and underdeveloped countries 
make economic progress impossible for the latter until they de-link or break economic links with international capitalism.

The African theorists further emphasize that neo-colonialism allows certain cartels of the state, such as the World Bank; to control and exploit less developed countries (LDCs) by fostering debt. In effect, Third World rulers give concessions and monopolies to foreign corporations in return for consolidation of power and monetary bribes. In most cases, much of the money loaned to these LDCs is returned to the favoured foreign corporations.

These Africans who argue that neo-colonialism historically supplanted or supplemented colonialism, point to the fact that Africa today pays more money every year "in loan interest payments" to the International Monetary Fund/World Bank that it receives in loans from them, thereby often depriving the inhabitants of those countries from actual necessities. This dependency they maintain, allows the IMF/WB to impose Structural Adjustment Plans upon these nations; adjustments largely consisting of privatization programmes, which they say, result in deteriorating health, education, an inability to develop infrastructure, and in general, lower living standards.

However, African critics of neo-colonialism and the IMF have conducted studies as to the effect of its policy which demands currency devaluations as a condition for refinancing loans, while simultaneously insisting that the loan be repaid in dollars or other first World currencies against which the underdeveloped country's currency had been devalued. This increases the respective debt by the same percentage of the currency being devaluated, therefore, amounting to a scheme for keeping Third World and African nations in perpetual indebtedness, impoverishment and neo-colonial dependence.

According to Chikendu (2006), the imperial powers have numerous agents that help them to actualize their neo-colonial intentions. These include the International Monetary Fund IMF, the World Bank, and the Multinational Corporations (MNCs).

The International Monetary Fund is a specialized agency of the United Nations established by the Bretton Woods Monetary and Financial Conference in 1944 putatively to promote international monetary cooperation. Its major objectives include:

(1) Promotion of exchange stability

(2) Establishment of a worldwide multi-lateral payments system; and

(3) Provision of monetary reserves to help member nations overcome short run disequilibrium in their balance of payments.

This apparently well-mentioned institution has become a tool for perpetuating the economic dependence of the new states by its policy and its advice to the new states which always turn out to be not in their best interest, but in the interests of the imperial powers Chikendu (2006, p. 124). Thus IMF decisions are usually reached by the "group of ten" a caucus of the major industrial powers which cast most of the votes in the Fund.

Again, the World Bank also called International Bank for Reconstruction and Development (IBRD) was also established by the Bretton Woods Agreement of 1944 to help nations recover from World War II and "to provide economic development in underdeveloped land". In collaboration with the IMF the World Bank policies have also become a veritable means to perpetuate the dependency status of the neo-colonial states of the world.

Dunning, (1974), in Mbah (2012) defined Multinational Corporation as a business enterprise which owns and controls income flow and generating assets in more than one country. It is also defined as that enterprise which has its operating headquarters located in a developed country with its subsidiaries spread in a number of countries. The Wall Street Journal, January (1972), says that there is no universally accepted definition of multinational corporation, but they are generally agreed to be those companies having production facilities in many lands, having access to capital worldwide, and having a global outlook among their management.

According to Mbah (2012, p. 46), multinational corporations are giant private business companies with global organizational characteristics flowing from parent countries to subsidiaries in host countries. MNCs are in global business for profit making. They are not charitable institutions. They are otherwise known as world business managers. They have global outreach by virtue of their capacity to control large stock of global capital, technology and market ideology which are spread to subsidiaries all over the world. The global inter-connectedness of MNCs confer on them, high power valence and great capacity to influence even host economies. The main feature of $\mathrm{MNC}$ is that it sets focus on profit maximization to the total exclusion of its host country, especially in the case of Third World Countries.

Onimode (1983), critically remarks that they are Trojan horses whose monopoly of capital and advanced technology, backed by enormous political pressure from their home governments, constitute the dominant mechanism for integrating Third World Countries more closely, and more pervasively, into the international system of capitalist domination. These exploited countries are ossified in the dependent status of a peripheral neo-colonial capitalist system.

The Multi-national Corporations are the active agents of neo-colonialism Chikendu, (2006, p. 125). The subsidiaries of giant multinational corporations were rapidly deployed by the imperialists after the flag independence of the Third World Countries to occupy the vacuum left by the departing colonialists. Because of their nominal separation from their host governments the MNCs enjoyed greater security and secrecy which enable 
them to operate in collusion with the comprador bourgeoisie of their client states, and engage in behind-the scenes political, diplomatic and military activities as dictated by their home governments, and imperialist international agencies such as the IMF and the World Bank. The MNCs sometimes sponsor political parties, finance coups d'état, and change governments in their host countries in order to enhance their plundering activities.

Worst part of the whole thing is that many of the Third World leaders, sometimes deliberately, and sometimes unwittingly collude with these MNCs by throwing their countries wide open to imperialist plunder by their policy of the so-called "open door" whereby they putatively attract foreign capital. According to Chikendu, the MNCs have dominated the productive forces in the neo-colonial economy. Thus in the urban areas and strategic sectors of the economy; such as mining, manufacturing, petroleum, finance, distribution, transport and communication, these imperialist agents dominate, the MNCs dominate. This has been made possible by their monopoly of sophisticated technology.

In the final analysis, NNCs are facilitators of underdevelopment and not agents of any host country's development Mbah (2012, p. 58). The articles establishing MNCs do not put obligation on them to develop their host countries. They constitute a mixed blessing. Their activities in host countries are neither entirely negative nor positive. For any contribution made by MNCs are usually incidental.

Tracing the causes of these problems, Mardof (1978), noted that the foundation of today's conditions in Africa, was laid long ago by Europeans through violence, slavery, and colonization. These conditions, he explains, are now maintained through institutions established in the colonial period. Africans must restructure these in situations to serve their needs if they wish to overcome the existing problems.

In his book "False Start in Africa" Professor Rene Dumont (1969) asserted that much of Africa's problem can be resolved "in twenty years". This is believable because with all its resources all that the continent needs in order to accomplish such a feat are leaders with vision and the courage to reject domination and exploitation.

For this research, the benefit resulting from consulting 'False Start in Africa' consists primarily of a widening of view regarding the areas to be considered in attempting to identify indicators of neo-colonialism. It is worthy of note to mention that many African nationalists and critics of colonialism see the independence gained from the withdrawing colonial powers as only partial liberation. Some call it 'false independence'. Full or real freedom, they believe, will come with economic independence. African nations are said to be currently in a phase of neocolonialism - a new form of imperial rule stage managed by the colonial powers to give the colonized the illusion of freedom. At the 1961 All-African People's Conference held in Cairo neo-colonialism was defined as "the survival of the colonial system in spite of the formal recognition of political independence in emerging countries which become the victims of an indirect and subtle form of domination by political, economic, social, military or technical means."

The implication is that western powers still control African nations whose rulers are either willing puppets or involuntary subordinate of these powers. The main economic theories supporting the neo-colonialism concept come from the dependency school developed in the late 1950s by Marxist economists who initially focused on Latin America. According to them poor countries are satellites of developed nations because their economies were structured to serve international capitalism. The natural resources of the satellites are exploited for use in the centre. The means of production are owned by foreign corporations who employ various means to transfer profits out of the country rather than invest them in the local economy. So what these countries experience is the 'development of underdevelopment'. The unequal relations between developed and underdeveloped countries make economic progress impossible for the latter until they break economic links with international capitalism. Only by becoming socialist can they hope to develop their economies. Some theorists went further to postulate that revolution in dependent countries would not be enough because of the structure of world capitalism that has made any national development impossible. Only the ending of capitalism at the centre would permit underdeveloped nations to achieve development. As desirable as it would be for African nations and indeed the world to become socialist, the experiences of former Third World nations that have transformed into advanced economies, made the generalizations of the dependency school less credible in the 1990s.

In the case of Nigeria which is the case study of this present work, since Britain dismantled its colonial administration in Nigeria October 1, 1960, "Nigeria" has "come to be regarded throughout Africa as a classic case of neo-colonial state. The reasons for this attitude are to be found in some of the developments in Nigeria before and after the country's attainment of political independence.

One of the first British moves in a conscious effort to prepare Nigeria for eventual independence was the introduction of a new constitution. The Richards Constitution of 1945, a constitution named in honor of its proponent, Sir Arthur Richards who was then the Governor of Nigeria. The Richards Constitution divided Nigeria into three regions (north, east, and west) each with its own House of Assembly "to channel demands to" the central legislature in Lagos presided over by the governor. While this constitution satisfied northerners' “... agitation for a separate and independent development of the Northern Region" the centrally minded easterners and westerners regarded it as an attempt to sabotage national unity through "a stratagem of divide and rule" and mounted a vigorous campaign against it. This pressure notwithstanding, the Richards Constitution was replaced with the 
MacPherson Constitution of 1951 which "transformed the regions into complete political and governmental systems.

The last constitutional changes preceding the granting of independence were those of 1954 and 1957. Each strengthened the principle of regionalism introduced by the Richards Constitution. One of Nkrumah's definitions of neo-colonialism is that:

The essence of neo-colonialism is that the state which is subject to it is, in theory, independent and has all the outward trappings of international sovereignty. In reality its economic system and thus its political policy is directed from outside. Nkrumah argues that neo-colonialism was conceived as a measure for remedying a potentially dangerous situation that confronted the rich in capitalist Western Europe after World War II. Before the war, the "great gulf between the few rich and the many poor" in the capitalist countries of Europe had forced some alliance between colonial subjects and workers in the capitalist centers (Nkrumah, 1965).

In this work, discussions will be on the Nkrumah's though on neo-colonialism, origin of Neo colonialism, the characteristics of Neo colonialism, and the negative and positive impacts of Neo colonialism in Africa.

\subsubsection{Gap in Literature}

In the above reviews, scholars have examined the meaning of neo-colonialism, Nkrumah's thought on neocolonialism and how it affects the current African situation of development. Also, dependency and imperialism were examined. The gap in literature is that imperial governments have aimed at controlling other nations through indirect means. Again that in lieu of direct military-political control, neo-colonialist powers employ economic, financial and trade policies to dominate less powerful countries. Therefore, African nations are said to be currently in a phase of neo-colonialism, a new form of imperial rule stage-managed by the colonial powers to give the colonized the illusion of freedom in well managed modern colonies. So, African political theorists (Fantahun (2013; Chandy, 2015) hold the view that western powers still control African nations whose ruler are either willing puppets or involuntarily subordinates of these super powers. The economies of African nations are structured, by virtue of their colonial experiences to serve international capitalism. The natural resources of the satellites are exploited for use in the centre. The major gap being that neo-colonialism operates through the various imperialist links earlier put in place by the colonial powers before and during the era of colonialism. It is possible because, in most cases, the major political economic and socio-cultural ideas, belief, norms, values, practices, structures and institutions introduced by the respective colonial imperialist powers were not dismantled at independence (Babatola, 2013). Up till today, it has not been possible to win the struggle against this new form of colonialism, but the struggle continues.

\subsubsection{Theoretical Framework}

African countries have not been completely independent from the imperial powers, which is to say that African countries are still under the shackles of neo-colonialism. What it implies is that complete economic freedom in Africa has remained a desire highly pursued but less realizable in Africa, due to the fact that socio-cultural, political and military independent has not been guaranteed. This study is therefore, anchored on the "dependency theory". According to Ferraro (1999, p. 1), dependency theory was developed in the late 1950s under the guidance of the Director of the United Nations Economic Commission for Latin Africa, Raul Prebisch. Prebisch and his colleagues were troubled by the fact that economic growth in the advanced industrialized countries did not necessarily lead to growth in the poorer countries. Mbah \& Obiora, (2015, p. 233), maintained in their book: "State and Economy: A Study in Third World and Dependency", that economic activity in the richer countries often led to serious economic activity in the poorer countries. This partly explains the deepening of the practice of neo-colonialism in Africa. The forward solution for neo-colonialism according to Nkrumah, is for the African states to stand together politically, to have a united foreign policy, a common defence plan, and a fully integrated foreign policy, a common defence plan, and fully integrated economic programme for the development of the whole continent.

However, it is the ability of these theoretical explanations to properly capture the Nkrumah's thought on neocolonialism and its effect on the contemporary Africa that it became appropriate to frame the current on "dependency theory". The theory which attempts to explain the present state of many nations in Africa and (other parts of the world), by examining the patterns of interactions and relationships among nations and by arguing that inequality among nations is an intrinsic part of those interactions. Dependency theory explains the effect of neocolonialism on neo-colonial states and the benefits the imperial powers derive from practicing neo-colonialism and proffers adequate solution in a bid to gain complete and real independent for the continents suffering from neo-colonialism (Africa in this study).

Prebisch's initial explanation of the dependency theory was very straight; poor countries exported primary commodities to the rich countries who then manufactured products out of those commodities and sold them back to the poorer countries. In order to maintain this new form of colonialism in Africa, (neo-colonialism), the imperial powers still maintain this relationship of unequal relationship to control Africa both militarily, political, sociocultural, economic etc. again, this type of relationship made Africa perpetual producers of what they do not use, and perpetual consumer of what they do not produce. Also, the "value added" by manufacturing useable product costs more than the primary product used to create those products Mbah \& Obiora, (2015: 233). Therefore, poor 
countries would never be earning enough from their export earnings to pay for their imports. This theory sincerely explains the implications of neo-colonialism on the neo-colonial states and also, proffers the best solution in reducing to the barest minimum the deepening of this new form of colonialism in Africa by the imperial powers, and to deal with the neo-colonialism and dependency phenomenon confronting the African continent.

\subsubsection{Application of the Theory}

As earlier stated, Nkrumah says that the greatest danger at present facing Africa is neo-colonialism and its major instrument, balkanization. One of the major features of neo-colonialism is that it creates client states, independent in name but in point of fact pawns of the very colonial power which is supposed to have given them independencethe European power forces, the conclusion of pacts with the balkanized states which give control of their foreign policy to the former. Implication of this is that the state which is subject to neo-colonialism is, in theory, independent and has all the outward trappings of international sovereignty. In reality, its economic system and thus its political policy is directed from outside. This is neo-colonialism in its actual and practical sense.

Again, Nkrumah said that the conversion of Africa into very small states is leaving some of them with neither the resources nor the manpower to provide for their own integrity and viability. Without the means to establish their own economic growth, they are compelled to continue within the old colonial trading framework. Hence, they are seeking alliances in Europe, which deprived them of an independent foreign policy and perpetuate their economic dependence. But this, he argues, is a solution that can only lead backwards, not forwards. The forward solution is for the African states to stand together politically, to have a united foreign policy, a common defence plan, and a fully integrated foreign policy, and fully integrated economic programme for the development and independence of the whole continent. Only then can neo-colonialism and his handmaid "balkanization" be overcome

\subsection{Method of Data Collection}

This study adopted the critical discourse analysis in examining the secondary data on previous works done in this area of study while paying attention to the position placed African continents by neocolonialism ideology of the western world. Further this paper used descriptive analysis which entails the use of secondary sources of data in presenting research details. Drawing from the classification of research method by Obasi, (1999) this study was based on the ex-post factor. The data for this study was analyzed using qualitative and descriptive analysis of information presentation.

\subsection{Characteristics of neo-colonialism and poverty of development in Africa}

Nkrumah says that the greatest danger at present facing Africa is neo-colonialism and its major instrument, balkanization. One of the major features of neo-colonialism is that it creates client states, independent in name but in point of fact pawns of the very colonial power which is supposed to have given them independence-the European power forces, the conclusion of pacts with the balkanized states which give control of their foreign policy to the former. It also act covertly, maneuvering men and governments, free of the stigma attached to political rule. Often too, they provide military basis and standing armies of the alien power on the territories of the new states. The independence of those states is in name only, for their liberty of action is gone.

The conversion of Africa into very small states is leaving some of them with neither the resources nor the manpower to provide for their own integrity and viability. Without the means to establish their own economic growth, they are compelled to continue within the old colonial trading framework. Hence, they are seeking alliances in Europe, which deprived them of an independent foreign policy and perpetuate their economic dependence. But this, he argues, is a solution that can only lead backwards, not forwards.

Mark (2017), in his work: "Neo-colonialism and poverty of development in Africa" realized that Neocolonialism has wrongly lost currency as a concept for examining African 'development'. This is reflective of university environments in which politer debate about global value chains or the misrule of the 'Big Men' more readily secures external income streams. There is real urgency to once more engage the concept of neo-colonialism to better understand - and critique - donor governments' and foreign corporations' behaviour in Africa. In doing so, we can more properly grasp current dilemmas with 'development' in the continent. This is what his recentlypublished work with Palgrave Neo-colonialism and the Poverty of 'Development' in Africa hopes to achieve.

As defined by Kwame Nkrumah, the concept of "neo-colonialism" warns us of the potential regressive impact of unregulated forms of aid, trade and foreign direct investment in relation to poverty reduction and wellbeing in African countries. This underscores how African state sovereignties can be reduced to mere "flag independence" by external policy interference and economic control (Kasongo, 2010). It does not deny that African elites may engage in wrongdoing, whether corruption, nepotism or human rights abuses. On the contrary, it asks us to acknowledge and contextualize instances of mal-governance in terms of how external donors and companies often encourage such actions to preserve lucrative economic arrangements in Africa.

Notably here, Nkrumah's key text, Neo-colonialism provokes immediate political reaction from the USA at the height of the Cold War. Less than a year after it was released, President Nkrumah was overthrown in a military 
coup abetted by Washington.

Mark's work, published in 2017, is written 60 years after Nkrumah led Ghana to a legal form of independence from British Empire in 1957. Notwithstanding six decades of 'development', large sections of Ghana's society remain impoverished and Nkrumah's warnings about external intrusions upon African sovereignty appear as relevant as ever. This is a tragedy one which external donors and corporations continue to exacerbate.

For example, his work details the marriage of corporate interest and donor aid in the case of the New Alliance for Food Security and Nutrition (NAFSN). Ostensibly aiming to end hunger in recipient nations such as Ghana and Malawi, the NAFSN has been seen to facilitate 'land-grabbing' amid creation of 'agricultural corridors'. Namely, subsistence farmers appear to be dispossessed in favour of the agribusiness needs of corporate NAFSN partners (including in export crop sectors such as palm oil). The New Alliance is backed by donors including UK DFID and USAID - whose aid lubricates African governments' acquiescence to land 'releases'. Donor support toward NAFSN agribusiness interests is publicly legitimized in terms of the UN Sustainable Development Goals (SDGs).

This is just but one example of how regressive donor and corporate interventions continue to stifle genuine opportunities for pro-poor growth in African countries.

His work like Nkrumah's will likely raise objections from the donor community and from those academics who constitute their clientele. Nevertheless, it is necessary to confront the realities of neo-colonialism which continue to exist in African contexts. To refuse to confront these realities from a position of academic privilege is a dereliction of duty and a betrayal of the wellbeing of poorer peoples on the continent. Only by recovering Nkrumah and the concept of neo-colonialism can current writers hope to meaningfully confront the dilemmas of (under)development that continue to affect millions of poorer Africans.

\subsubsection{The impacts/Implications of neo-colonialism on African Continent}

In order to understand the impact of neo-colonialism you first have to look at the reason for neo-colonialism. Nothing much remains to be said other than that neo-colonialism is those modern attempts to perpetuate colonialism while at the same time talking about "freedom" or independence. It is in fact, akin to a divorce with alimony since all neo-colonial states are not masters of their own fate.

- The main reason for neo-colonialism is that developing nations (aka periphery nations) generally do not have the capital available to develop their own natural resources, so well-developed (core) countries and wealthy trans-national corporations offer to cultivate these resources in exchange for a high percentage of the profits. The core countries/corporations attain the majority of the profits from such ventures due to the low price of labor inmost periphery nations.

Thus one of the most obvious impacts is that corporations and core countries get very rich through utilizing developing countries resources. Wealth in developing countries is also fostered as a result of this development, but often the wealth does not trickle down to the ordinary person/worker.

In the words of Odoziobodo \& Omemma (1999), politically, most post independence African countries are at pains to establish a viable, stable and virile democratic policy. As a result, there have been rampant incidences of military intervention in politics to set things right. But how far the military have been able to redeem their pledge while taking over power, is a matter that posterity shall vindicate.

Economically, the neo-colonial African economies are vulnerable to imperialist manipulations and distortions emanating from the centers of international capitalist economies. The involvement of transnational giants and other multilateral corporations in the economic activities of neo-colonial countries hamper the efforts of these countries to exercise sovereignty over their economic resources. Consequently, the citizens of neo-colonial Africa are constantly experiencing deprivation exploitation and marginalization by two parts; the external and internal. Internally, the emergent bourgeois ruling and business as well as traditional elites (centre of the periphery) are engaged in "primitive accumulation" to the detriment of the generality of the populace. In some cases, the intraelite scramble for political powers and economic domination result in severe break down of law and order and at times civil wars. Nigeria, the Congo Republic, Somalia, Sierra Leone, Liberia etc, provide a refulgent example.

Externally, the metropolitan neo-colonialist powers (Centre of the Centre) penetrate into neo-colonialist economies through the indigenous bourgeois; who serves as conduit-pipe if you like commission agents (i.e. Comprador Bourgeoisie) and the transitional corporations to exploit the state and the people. Indigenous elites' neo-colonialist's collaboration in this strategy of "dual exploitation" and distortion of the economies of neocolonial countries have continued unabated in most African states since independence. This act of un-patriotism perpetrated by the emergent African ruling class has been aided by the neo-colonial environment created and strengthened by imperialist powers and their agencies throughout the continent of Africa.

In sum, neo-colonialism and imperialism have rendered Africa dependent on outside powers for development. And this can be seen from the foreign "aids", loans, grants and investment, which the continent relies upon for development. These loans in turns have created serious condition of debt burden and crisis for the continent. The debt crisis tends to render foreign loans unpalatable for Africa's development since it is akin to filling a perforated drum with water without first examining the drum and plugging any such holes. In view this argument, it is 
imperative that our leaders de-emphasize foreign loans as development strategy. In fact, foreign loans, particularly from capitalist-imperialist powers are tools of misadvise for the perpetuation of African impoverishment and dependency.

In a similar development, the involvement of multinational corporations in the mining, petroleum, industrial, manufacturing, banking, commercial and construction sectors of Africa's economy and the role of Africa's indigenous quislings make it extremely difficult for the continent to exercise meaningful autonomous influence over its strategic resources. Neo-colonialism and imperialism have also made the continent to remain dependent on outside technology and foreign experts for the exploration, exploitation, processing, distribution and marketing of its vital products.

They maintained further that another impact of neo-colonialism on Africa is the intermittent political instability. Starting from the period of slave trade and colonization and inception of apartheid system in South Africa, the imperialist powers have been the brain behind major political crisis in the continent. The Congo crisis in the 1960s, the armed liberation struggles in Zimbabwe, Angola, Mozambique, Namibia, the Nigerian Civil War and subsequent military coups, the Liberian, Chadian, Sierra Leonean, Somalia, Rwandan, Burundian Crisis etc. have been linked with one imperialist centre or another. It is a clear and known fact that, it is easier for a camel to pass through the eye of a needle than for a continent riddled with interminable political imbroglio and internecine wars to pursue and achieve a meaningful development. Therefore, one can blame neo-colonialism for the interception, disruption, truncation, obstruction, distortion, and even destruction of developmental strategies in Africa.

According to the United Nation World Tourism Organization and Development 2013, other impacts/implications of neo-colonialism to African continent is that Tourism in regions such as the Caribbean is often seen as an example of neo-colonialism. Here is an excerpt from an article which details many of the impacts of neo-colonialist tourism:

Many developing island countries cannot avoid the perceived growth potential tourism development presents. It is recognized as a mechanism to foster economic growth (United Nation World Tourism Organization, 2013) and development. For those countries, tourism development is considered an alternative for economic growth since there has been a decline in the traditional industries, namely, manufacturing and agriculture. It generates social harmony and helps in the preservation of local cultures and the environment. Regardless of these economic, social, cultural and environmental benefits, tourism activities are also deemed as having negative effects. Tourism activities can negatively influence local economies, for example through economic leakage. They can likewise damage the natural and physical environment on which tourism depends. Also, the culture of host communities can be negatively influenced due to the erosion of traditional values. See Gaunette Sinclair-Maragh, Dogan Gursoy, Imperialism and tourism: The case of developing island countries, p. 145. (http://users.du.se/ rem/Sinclair...)

The 'economic leakage' refers to what was mentioned earlier; that much of the profits go to the developer rather than the developing countries. The 'damage' of the natural environment refers to how mega hotels and cruise ships cause damage to the natural landscape and habitat (through pollution etc). Often developing countries do not have sewer systems built for human waste, so mass tourism exacerbates human waste problems too (due to overpopulation during tourist season). For an example of this problem see http://blogs.discovermagazine.co.... The cultural erosion described in the above quote refers to resorts whose nature is incomplete dichotomy to Caribbean culture (e.g. the controversial Hedonism II and III resorts). Overall, economic leakage is what would be described as the main impact. Economic leakage is widespread throughout developing countries.

\subsection{Summary of Findings}

In summary, this research work which was based on Nkrumah's thought on neo-colonialism and Africa's development, found out that: The "classical contribution of Kwame Nkrumah to African political thought and practice is his work Neo-Colonialism: The Last Stage of Imperialism”. This is the book which, when first published in 1965, caused such uproar in the US State Department that a sharp note of protest was sent to Kwame Nkrumah, and the \$25 million of American "aid" to Ghana was promptly cancelled. It exposes the working of international monopoly capitalism in Africa and shows how the strangleholds of foreign monopolies perpetuate the paradox of Africa: poverty in the midst of plenty. Nkrumah began his work with re-definition of neocolonialism. Accordingly, he sees neo-colonialism of today as representing imperialism in its final and perhaps its most dangerous stage. Nkrumah laments that imperialism still constitutes an African problem, but it is everywhere on retreat. In place of colonialism as the main instrument of imperialism we have today neo-colonialism. In undergoing this study we found out that:

1. African states are today independent of colonialism, they remain heavily dependent and exploited under effects of internal political failures, neo-colonialism and neo-liberalism. This is possible because, in most cases, the major political economic and socio-cultural ideas, belief, norms, values, practices, structures and institutions introduced by the respective colonial imperialist powers were not dismantled at 
independence.

2. Nkrumah Kwame (1965), stated that the essence of neo-colonialism is that the state which is subject to it is, in theory, independent and has all the outward trappings of international sovereignty. In reality, its economic system and political policy is directed from outside.

3. During the course of this study, it was discovered that neo-colonialism is a system of economic, political, military and other relations imposed by the imperialist states on the developing countries in order to keep them within the framework of the capitalist economic system. It is based on the economic backwardness, unequal and dependent state of the neo-colonial countries within the scheme of the world capitalist economic and political systems.

4. It was also found out that, the neo-colonial powers pursue their actions in the name of the United Nations by using two UN agencies that they established after World War and that they fully control without pretext of democracy, the World Bank and International Monetary Fund. Still another neo-colonialist trap on the economic front has come to be known as "multilateral aid" through international organizations. These agencies have the habit of forcing would-be borrowers to submitting their policy and plans to review by the World Bank and accepting agency supervision of their use of loans. This is in a bid to control the African continent and maintain the old dependency relations.

5. Because of the world capitalist system and the so-called international division of labour which sees Africa only as producers of primary commodities, most African nations have no viable integrated industries which can diversify their economies and supply the rest of the world with finished products. Mining production for example is designed for exportation. What stays in Africa is the wages paid for the mineworkers. Majority of money spent on salaries goes to Western directors, and much of the profit goes to Western Trans-national corporations.

6. Nations in the West are forming coalitions to integrate and protect their economies e.g NAFTA in North America and EU in Europe. Yet at the same time, poor developing countries in Africa, Asia and Latin America are continually urged by the World Bank and IMF to liberalize and remove protectionist policies from their economic programs.

7. Nkrumah states unequivocally, that the less developed (Africa) will not become developed through the goodwill or generosity of the developed powers. This is because, their vested interest is to keep them in perpetual poverty and underdeveloped through the greatest danger at present facing Africa (Neocolonialism) and its major instrument balkanization.

\subsection{Conclusion}

Going by the findings of this study we concluded that for Africa to overcome the problems of neo-colonialism and its instruments, in order to gain complete economic and political independence, African continent should fight and struggle against the external forces which have a vested interest in keeping them underdeveloped. Nations in the West are forming coalition to integrate and protect their economies and keep African continent dependent on them, in perpetual poverty and underdeveloped, the do this through international organizations and Western multinational corporations. Again, African continent is in theory, independent and has all the outward trappings of international sovereignty. But in reality, its economic system and thus its political policy is directed from outside, in a bid to overcome neo-colonialism and it major instrument balkanization and guarantee development and independence in Africa, they should dismantle the major political economic and socio-cultural ideas, belief, norms, values, practices, structure and institutions introduced by the respective colonial imperialist powers.

\subsection{Recommendations}

1. All the ideas, belief, norms, values, practices, structures and institutions introduced by the respective colonial imperialist powers in Africa before independence, should be dismantled since the colonial days is over in Africa. This will enable the African continent to gain compete economic and political independence and become masters of their fate.

2. Since the African states are not in reality independent, due to the fact that their economic system and political policies are directed from outside, they should guarantee internal measures to direct their economic systems and political policies internally in order to be free from the shackles of neo-colonialism.

3. Nkrumah laments that imperialism still constitutes an Afrcan problem, but it is everywhere on retreat. In place of colonialism as the main instrument of imperialism we have ne-colonialism. He exposes the working of international monopoly capitalism in Africa and shows how the strangleholds of foreign monopolies perpetuate the paradox of Africa: Poverty in the midst of plenty. Therefore, African continent should de-link from relating with the Western imperialist powers in order to achieve economic and political freedom.

4. All this while, African continent is deeply entrenched in debt to the developed Western countries, much of these debts were acquired to fight the economic hardship, enhance development and minimize 
dependency, but have obviously failed to make any remarkable improvement in the situation. African countries should cease from receiving aids from these Western countries and organizations for them to desist from being dependent on the Western imperialist countries.

5. Most of the African nations should make efforts to have and sustain viable integrated industries which can diversify their economies and supply rest of the world with finished products, so that the huge amount of money being spent on the salaries of the Western directors and much profits that goes to their Transnational corporations should be channeled in fighting neo-colonialism, curtailing poverty in the African continent, developing them, and reducing their dependency tendencies to the barest minimum.

6. For Africa, redressing the issue of forming coalitions to integrate and protect their economies is an urgent challenge. Neo-colonialism and neo-liberalism make continental planning harder over time, because narrow national markets becomes structurally entrenched. However, neo-colonialism alone does not fully explain Africa's present-day dependency and developmental challenges. There is also the need to question and address the issue of corruption and failures of political leadership in Africa.

7. This study also recommends that African continent can only become developed through a struggle against the external forces which has a vested interest in keeping them underdeveloped and dependent on them (the Western countries) since the continent have overcome colonialism and have achieved political independence. They need to abolish entirely, the old fashioned colonialism.

\subsection{References}

A.U.N (1984). Basic facts about United Nations. A.U.N publication.

Ake, C. (1981). Political economy of Africa. Lagos: Longman.

Anuoluwapo, A. D. and Edwin, C. I. (2018). Neo-colonialism and Millennium Development Goals (MDGs) in Africa: A blend of an old wine in a new bottle. Accessed online from https://www.tandfonline.com/doi/citedby/10.1080/20421338.2018.1463654?scroll=top\&needAccess=true on $25^{\text {th }}$ February, 2020

Arowolo, D. (2010). The effects of western civilization and culture on Africa". Afro Asian Journal of Social Sciences, Volume 1, No. 1 Quarter IV, 2010.

Asante, M. (2007). The History of Africa. USA: Rutledge

Babatola , J. (2013).Neo-Colonialism In Africa: A Perpetuation Of Western Interest And Subjugation Of Africa

Babatola, J. (2014). Neo-Colonialism In Africa: A Perpetuation Of Western Interest And Subjugation Of Africa. Ekiti State University, Ado-Ekiti Department Of History And International Studies accessed online from file://C:/Users/HP'S/Downloads/NEO-COLONIALISMINAFRICA.pdf on $25^{\text {th }}$ February, 2020

Brown, M.B (1978). Economies of imperialism. London: Penguin books.

Chandy, L. (2015). "Why is the number of Poor People in Africa increasing when Africa's economies are Growing?" Brookings, Accessed February 6, 2020. https:/www.brookings.edu/blog/Africa-infocus/2015/05/04/why-is-the-number-of-poor-people-in-africa-increasing-when-african-economies-aregrowing.

Chikendu, P.N (2004). Imperialism \& nationalism. Enugu: Academic publishing company.

Chinweizu (1974). The west and rest of us. Cambridge: Massachusetts.

Curtis, M. (2016). The New Colonialism. War on Want Campaign

Egbomuche, O. L. (2006). The political thought of Africa. Onitsha: Golden value books.

Ejiofor, L. U. (1981). African in world politics: the growth of African presence in United Nations (1945-1970), a political-historical survey. Onitsha: Africana educational publishers (Nig) Ltd.

Fanon, F. (1963). The wretched of the earth. New York: Grove press http://blogs.discovermagazine.co...http://users.du.se/rem/sinclair, Gaunette Sinclair-Maragh, Dogan Gursoy, Imperialism and tourism: The case of developing island countries, p. 145.

Fantahun, M. (2013). "Africa-China Relations: Neocolonialism or Strategic Partnership? Ethiopia as a Case Analysis." PhD diss., Atlantic University.

Irele, F. A. (2010). Westernization. http://science.jrank.org/pages/8152/westernisation.

Karl Marx (1853). The future result of the British rule in India. New York tribune, No. 3840. August 8, 1853.

Karl, Marx (1870). Capital vol.1. China: Moscow progress press.

Kasongo, K. (2010) "Impact of Globalization on Traditional African Religion and Culture Conflict" Journal OF Alternative Perspectives in the Social Sciences. Vol.2. No. pp. 307-322

Lenin, V. I. (1933). Imperialism; The highest stage of capitalism. China: Little library publishers.

Magdoff, H. (1978). Imperialism: From the Colonial Age to the Present. New York: Monthly review press.

Mark L. (2017). Lets talk about neo-colonialism in Africa. Hotmail accessed from https://blogs.lse.ac.uk/africaatlse/2017/11/15/lets-talk-about-neo-colonialism-in-africa/ on $25^{\text {th }}$ February, 2020

Mark L. (2017). Lets talk about neo-colonialism in Africa. Hotmail accessed from 
https://blogs.lse.ac.uk/africaatlse/2017/11/15/lets-talk-about-neo-colonialism-in-africa/ on $25^{\text {th }}$ February, 2020

Mark, L. (2017). Neo-colonialism and poverty of development in Africa. http://usesrs Africa, accessed Nov.15th 2017.

Mbah, C.C \& Obiora, C. A (2015). State and economy, a study in third word and dependency. Nimo: Rex Charles and Patricks Ltd.

Mbah, C.C. (2006). Political theory and methodology. Nimo: Rex Charles and Patricks Ltd.

Mbah, C.C. (2012). African politis: An introduction. Nimo: Rex Charles and Patricks publications.

Nkrumah, K. (1963). Africa must unite. London: Educational books limited.

Nkrumah, K. (1965). Neo-colonialism: The last stage of imperialism. London: Heinemann.A.U.N Publication.

Nkrumah, K. (1968). Message to the black people of Britain, from revolutionary path, 1973, http://www.google.com

Nyikal, H (2005). Neo-colonialism in Africa: The economic crisis in Africa and the propagation of the status quo by the World Bank/IMF and WTO. ENG297C.

Obasi, I. (1999). Politics and globe dictionary. Aba: Eagle.

Obasi, I. N. (1999). Research methodology in political science. Enugu: Academic publishing company.

Obi, E. A. \& Nwanegbo, C. J. (2006). Development administration: Theory and applications. Onitsha: Bookpoint Ltd.

Odoziobodo, I \& Omemma D.A (1999). Fundamentals of African politics. Enugu: Education promotion publishers. Olatunji, S. A. (2010). "Thematic changes in postcolonial African literature: From colonialism to neocolonialism", Sino-US English Teaching, 2010, Volume 7, No.10 (Serial No.82).

Olatunji, S. A. (2010). "Thematic changes in postcolonial African literature: From colonialism to neocolonialism", Sino-US English Teaching, 2010, Volume 7, No.10 (Serial No.82).

Onimode, B. (1983). Imperialism and underdevelopment in Nigeria. Lagos: Macmillian Nigeria Ltd.

Onimode, B. and Richard, S. (eds.) (1995). Issues in African development: Essay in honour of Adebayo Adedeji at 65. Ijebu-Ode: ACDESS

Organization of African Unity (OAU), becomes the African union (AU). Wikipedia: Http://www.google.com Organization of African Unity, Encyclopedia. Columbia University press.

PAN African (2002). The NEPAD formula. Serah Coleman. World press review. Vol.49 No.17.

Pather. S. (2019). Confronting inclusive education in Africa since Salamanca. International Journal of Inclusive Education 23:7-8, pages 782-795.

Rodney, W. (1972). How Europe underdeveloped Africa. Dare Salam: Tanzania press.

Sofola, J. A. (1978). African culture and the African personality: What makes an African person African. Ibadan: African resources publishers co.

The Wall Street Journal (1972). United State's newspapers. United State's printer.

Theotonio, Dos Santos (1971). The structure of dependency, in Fann, K.T. and Donald Hodges C. (eds.), reading in U.S. Imperialism. Boston: Porter sergeant.

Todaro, M. P. and Smith S. C. (2003). Economic development. New Delhi: Pearson education Ltd.

UNCTAD (1999). Trade and development report. New York: The United Nations.

United Nation's Economic Commission for Africa (2002). The African peer review mechanism's process and procedure. African security review vol. 11.

United Nations World Tourism Organization and Development (2013).

Volkov, M. I. (Eds.) (1981). A dictionary of political Economy. Moscow: Progress publishers 